\title{
Size Matters: Strength of Force in Peace building Missions
}

Author: Frances Reka Fink

Faculty Mentors: J. Michael Greig, Ph.D., and Eric Keels. Department of Political Science, College of Arts and Sciences, University of North Texas

Department and University Affiliation: University of North Texas, Department of Political Science, College of Arts and Sciences 


\section{Bio:}

Frances R. Fink is a senior studying political science at the University of North Texas.

She is a member of the debate team and a supplemental instructor for introductory classes in American Government, and also serves as the student ambassador from the Department of Political Science to the College of Arts and Sciences. After graduating with a Bachelor of Arts degree in political science, she plans to either attend law school or pursue a graduate degree in public policy. 


\begin{abstract}
:
Previous theoretical work on peace building describes a 'footprint dilemma' regarding the appropriate size of force. In the preliminary stages of peace building, third party forces that tread with a heavy footprint can deter violence, but risk inciting backlash. A smaller force with a lighter footprint may receive less resistance but lack the strength needed to achieve goals. This project proposes that a larger force is more likely to achieve a lasting peace and will facilitate operations in other areas, such as electoral and economic reforms. A logistic regression of 1,077 peace spells following civil wars establishes a relationship between the size of peacekeeping forces as a percentage of population and the likelihood of peace failure. These results indicate that the risk of conflict drops dramatically once peacekeepers represent 1.5 percent of the state population.
\end{abstract}




\section{Introduction}

Since the end of the Cold War, a new international trend has emerged in conflict management: instead of short-term interventions with a narrow focus on brokering a cease-fire to end hostilities, third parties are turning towards larger, more dynamic 'peace building' operations designed to prevent civil war recurrence by increasing the state's capacity to manage conflict (Doyle and Sambanis 2000). The prevailing method of peace building has focused on political and economic liberalization, but recent studies using quantitative tools to evaluate the long-term effect of these reforms have cast doubt on their ability to create stable peace. Considering these observations, the next step is to ask "Is there a better way to build peace?" Theoretical answers to this question have been proposed, but few rest on the grounds of statistical evidence.

The work that follows attempts to bridge this gap by proposing a combination of basic security and economic development as an alternative to status-quo peace building. Despite emphasis on the creation of a secure environment in qualitative descriptions of peace building, researchers have not found a relationship of significance between peace and security. Similarly, proposals of job creation and social service provision that are well-grounded in theory are not supported when put to the statistical test. However, when novel measurements of peacekeeping force are used in this paper, they produce different results.

This paper will outline the competing theories on overall strategy (i.e., how a multidimensional mission should proceed at the macro level), and then describe how each dimension itself has multiple options that peace builders can pursue. Next, I introduce a theory based on previous literature that offers a different approach to multidimensional peace building, developing expectations on how increased security and economic well-being will change the 
likelihood of peace failure. These hypotheses will be tested with a logistic regression using the peace spell data set from Mason et al. (2011).

\section{Review of Previous Work}

Peace building methods are still a subject of debate within the field of peace studies, but there is a general consensus on which policy areas must addressed. The list includes the establishment of a secure environment, the restoration of state institutions such as electoral systems, and economic reform. Within each dimension (military, political, and socioeconomic), there are competing views about which reforms are most conducive to long-term peace. The following review of peace building literature will summarize current findings and frame the investigations to be conducted in the second half of this paper.

\section{The Military Dimension}

The end of a civil war leaves the populace in the midst of a 'security dilemma': the state has essentially collapsed, and parties to the conflict must attempt cooperation without the guarantee of security against attack from rival groups during the process of demobilization (Walter 1999). This dilemma must be resolved by a credible commitment to oversee the transition and provide collective security.

Previous work has found that peace building missions decrease the likelihood of renewed civil war (Doyle and Sambanis 2000; Mullenbach 2006), but less quantitative research exists on how the size of the force used to conduct these missions affects the duration of peace. Birgin Heldt operationalizes mission size as the total manpower deployed (troops, civilian police, and military observers) divided by the size in square kilometers of the mission location, but does find a relationship between success and mission size (Heldt 2002). The link between peacekeeping force and the duration of peace is also addressed by Virginia Fortna (2003) and Darya Pushkina 
(2006) who do not find a significant relationship. Both studies, however, use the type of mission — observer, traditional or multidimensional — as an indicator of the size of the mission, without controlling for the number of peacekeepers present.

Despite inconclusive results on how the number of peacekeepers interacts with postconflict efforts to restore order, the theoretical prescriptions for security reforms are wide ranging in the peace building literature. Authors agree on the basic need to provide security and the importance of demobilizing former combatants (Coyne and Boettke 2009; Doyle and Sambanis 2006; Krause 2005; Schwarz 2005), but little consensus exists on how basic security is best established or how those reforms should proceed in the context of a multidimensional peace building operation. Some scholars argue that security should be a foremost concern of peacekeeping missions, with a robust and well-equipped force to effectively police the transition (Diamond 2006, Zartman 1995); others caution that the introduction of a large, third party force could alienate the local population and result in the militarization of peace building operations (Chandler 2006; Chopra 2002; Marten 2004; Suhrke 2009).

This tradeoff between force and legitimacy is referred to within peace building literature as the "footprint dilemma" where 'footprint' describes the size of the intervention force and their prevalence within the state (Paris and Sisk 2009; 316). To create security in the preliminary stages of peace building, third party forces may tread with a heavy footprint in order to deter violence, but do so at the risk of inciting backlash from nationalist elements that resent the presence of a foreign occupying force (Edelstein 2009). Alternatively, a less-invasive force with a lighter footprint may receive less resistance from local groups but ultimately lack the requisite capacity to achieve their goals (Edelstein 2009). 
Advocates of expanding the security dimension of peace building operations contend that international military intervention is the only way to fill the vacuum of power created by state failure (Diamond 2006). While the use of force by a peace building mission seems contrary to its stated objective of eliminating conflict, scholars claim that coercive measures can induce peace by containing violence before it ignites full-scale civil war (Labonte 2004). Since military intervention also lowers the probability that a group will be able to strike its enemies without warning, it may remove the incentive for a preemptive attack by reducing the amount of uncertainty in the post-civil war environment (Chassang and Miquel 2010).

Of peace building scholars who are critical of the prospects for creating peace through military means, many question the viability of international solutions to local problems (Bellamy and Williams 2010; Paris 2010). Richard Caplan and David Chandler argue that a large occupying force with absolute decision-making power undercuts any preexisting local institutions in the post-conflict society, and results in an underdeveloped state that is dependent on the peace builders. The result is that the presence of a large force can enforce peace in the interim but fails to guarantee that peace will endure after the mission ends (Caplan 2005; Chandler 2006).

Instead of a large third party intervention force, critics of status-quo peace building argue that reforms should be led primarily by indigenous actors and local security forces (MacGuinty 2008). Some authors claim that peace builders should stay out of post-conflict states completely, recommending instead that the international community promote "autonomous recovery" without the use of international intervention (Weinstein 2005; 5). To support this argument, the experience of Uganda and Somalia are given as examples of when indigenous reconstruction 
efforts were more effective than previous attempts sponsored by foreign actors (Englebert and Tull 2008).

Given the amount of disagreement over the appropriate use of force in peace building missions, the lack of quantitative analysis on the footprint dilemma is surprising. Since the deployment of a mission that is strong enough to establish security without being overly intrusive is noted as a "crucial conceptual and strategic challenge for practitioners" (Paris 2010; 343), further analysis in this area is essential. If a footprint exists that is "just right," it could be a novel solution to the challenges of third-party peace building.

\section{The Political Dimension}

While critical to reconstruction efforts, provision of security in the post-conflict situation is a necessary but insufficient condition for successful peace building. Holding elections - the goal of the political dimension of peace building — is a fundamental component of restoring order after war and one of the only ways to gauge state legitimacy (Sisk 2009). Democratic processes are seen as conflict management tools, and UN peace building missions place heavy emphasis on post-conflict elections because they provide a peaceful outlet for grievances and promote the non-violent transfer of power (Krause 2005; Ottaway 2003). Unfortunately, states emerging from war may not experience the same benefits from democratic elections as peaceful societies, and post-conflict elections have often led to renewed violence (Mansfield and Snyder 2005; Reilly 2004). This is because the main competitors in the election are often former combatants, who may use violence to coerce voters or intimidate their opposition (Hoglund et al. 2009). Since there is a possibility of losing an electoral contest, parties who fear the election will cause their permanent exclusion from power may choose instead to resume war (Dunning 2011; Cederman et al. 2010). Finally, democratization is an "inherently conflict-exacerbating enterprise" (Sisk 
2009 ; 198), presenting a problem for peace builders who wish to promote reconciliation instead of competition (Jarstad and Sisk 2008).

The challenge of post-war elections is a widespread concern among peace builders, but policy prescriptions are largely theoretical and quantitative research on the interaction between elections and violence have only recently emerged. These studies hypothesize that the hazard created by democratization in the wake of civil war is related to the timing of the first election post-war (Brancati and Snyder 2012; Flores and Noorruddin 2012). To test this theory, Flores and Noorrudin create indicator variables which code for when the first post-conflict election was held - in the first year after conflict termination, the second year, the third year, or later. They find that elections within the first two years predict violence within the next three, but the probability of violence declines when elections are delayed until the third year.

This result lends statistical evidence to what has long been proposed in theoretical works (such as Paris 1997), but Flores and Noorrudin stop short of uncovering why delaying elections reduces the likelihood of conflict recurrence. They suggest, however, that it may be related to the additional development of state institutions that occurs when elections are held at a later date (Flores and Noorruddin 2012). Brancati and Snyder extend this analysis with an important addition: elections — even early ones — do not have destabilizing effects if conditions are favorable. They conclude that demobilization in particular lessens the likelihood of renewed fighting following electoral contests, most likely because the process of disarming former rebels limits their capacity to resume war if they are not satisfied with the results of the election (Brancati and Snyder 2012). Despite this finding, it is still unclear how peace builders can facilitate this outcome and how much demobilization must occur. Brancati and Snyder code demobilization as a dichotomous variable, with 1 representing a demobilization process which 
began before a post-conflict election and 0 for all other starting points. Since the DDR process need only have begun to be considered an instance of demobilization under their definition, it is unclear whether the extent of disarmament affects the likelihood of conflict after elections.

It should be expected however, that the extent of demobilization does matter in the context of peace duration, given the aforementioned observation that DDR programs reduce the capacity to wage war. Although estimates vary on how effectively DDR programs can remove arms from former combatants, there may be a way to compensate for the lack of data on demobilization. Since disarmament is most likely to occur when groups feel safe enough to hand over their weapons without fear of being left open to attack, the conditions under which third parties can provide a sufficient guarantee of security may affect the extent of demobilization prior to elections.

\section{The Socio-Economic Dimension}

The third component of successful peace building is a program to jump-start the stalled economies of post-civil war states. The predominant approach to reform in the socioeconomic dimension of peace building has been the use of structural adjustment programs, coordinated by the International Monetary Fund (IMF) (Hartzell, Hoddie and Bauer 2010; Paris 2004). These reform packages emphasize restrictions on government spending, deficit reduction, trade liberalization, higher taxes, and the privatization of state-controlled industries (Flores and Nooruddin 2009; Noruddin and Simmons 2006). Although IMF adjustment policies are intended to create liberal economies where the state's role is limited, studies indicate that such austere measures can exacerbate tensions in post-conflict states by reducing subsidies, employment, wages, and government investment (Cho 2004; Hartzell et al 2010; Paris 2004). When governments need to reduce deficits, they can either increase taxes or cut expenditures. Since the 
tax base in post-civil war countries is limited at best, most administrations choose to cut spending in order to meet IMF goals (Mahdavi 2004). These cuts usually target programs that provide economic and social assistance to the population, which disproportionately affects the most impoverished segments of society dependent on aid and who are unable to exit into the private sector (Nooruddin and Simmons 2006). By emphasizing balanced budgets and rapid liberalization, peace builders may increase the likelihood of renewed conflict by limiting the provision of critical public services (Zaum 2012).

Although a tentative consensus has emerged regarding the possibility that IMF structural adjustment programs can have negative effects on post-conflict peace, existing literature has not coalesced around an appropriate alternative. One possibility is the creation of new employment opportunities in the reconstruction period (Berman et al 2011; Sambanis 2004). By offering former combatants legitimate occupations that increase their level of economic well-being, peace builders may be able to raise the opportunity cost of fighting and thereby reduce the supply of rebel labor (Mason and Quinn 2006; Collier and Hoeffler 2004). This proposition is supported by Besley and Persson's research on how income affects the likelihood of political violence. They evaluate income shocks (e.g., a sudden wage change) using the number of extreme weather events, reasoning that meteorological phenomena like drought and rainfall affect the laborintensive agricultural sector. When extreme weather reduces agricultural production, wages are lowered to offset the losses. They conclude that these 'shocks' to income are associated with an increase in the incidence of repression and civil war (2011). Similar results are described by Dal Bo and Dal Bo, who find that negative shocks to labor-intensive sectors of the economy decrease the opportunity cost of rebellion by lowering wages (Dal Bo and Dal Bo 2011). 
Another possible solution to the ills of structural adjustment would be to increase government expenditures on social services (Call and Cousens 2008; Clapham 2003; Roberts 2008). The provision of public goods may interact with peace duration in two ways. First, social services such as public health programs and education provide the basis for economic accumulation. If individuals are sick or illiterate, their ability to generate income will likely suffer (Rotberg 2004; Lemay-Herbert 2009). Secondly, if the government is seen as a reliable source of public goods, it can lend legitimacy to the state and reduce the power of rebel groups who may have been the primary provider of those resources in war-time (Lake and Baum 2001). In this way, social services are viewed as a tool to "win hearts and minds" of the local population and increase the difficulty of rebel recruitment (Keefer 2010; 17).

The only quantitative analysis of public service provision and the likelihood of conflict is a study authored by Berman, Shapiro and Felter, who find that government spending on public goods reduces violence (2011). As their analysis is based on a case study of Iraq, the finding cannot be generalized across cases, but their result indicates that further research is required to measure this relationship. Besley and Persson offered such a corollary — that higher spending on public goods reduces the likelihood of civil war-but concluded that a hypothesis test was infeasible because data on public goods provision did not yield a sample large enough for analysis (Besley and Persson 2011).

\section{Theory}

Simultaneous military, political, and economic reforms such as those described above would be a challenge for policymakers in any context, but peace builders attempt this feat in the midst of an acute security dilemma. In this environment of uncertainty, distrust runs deep and there are powerful incentives to defect from the peace process (Doyle and Sambanis 2006). For 
peace builders, the most important role may be to facilitate commitment by supplying the deterrents to defection and the incentives for cooperation. Previous peace building missions have applied liberal political institutions and free-market policies toward these ends, but those strategies do not remove the underlying inequalities from which violence emerges and may actually push parties back towards war by fostering competition instead of cooperation. Instead, third parties can encourage commitment by using reform as a 'carrot' and their military presence as a 'stick' to realize their goals in the three critical dimensions of peace building.

\section{Impact of Security}

Previous studies have established that third party presence can defuse the security dilemma by providing credible commitment (Mansfield and Snyder 2005; McBride et al. 2011), but they do not establish if the size of the intervention force affects the duration of post-conflict peace. Observations from case studies indicate, however, that this may be an important relationship: in Cambodia, the size of the monitoring force relative to the strength of the groups under observation created gaps in oversight, allowing some groups to skirt the demobilization process. As a result, smaller groups refused to disarm after the Khmer Rouge was able to circumvent the UN demobilization process (Dobbins et al. 2005). In Afghanistan, the international force was initially small and had limited authority to conduct operations beyond Kabul, setting the stage for de-facto militia control over large areas of territory outside the capital (Lemay-Herbert 2009). The power wielded by militias in Afghanistan is an example of how groups will engage in 'self-help' activities if credible commitment to secure the post-war environment is lacking. We know that the physical presence of a third party can provide this much-needed security guarantee, but the experience of peace builders in these missions indicates the size of the intervening force may be important to the transition from war to peace. Thus, we 
should expect that the ratio of peace builders to the population being monitored is related to the likelihood of peace after war- because individuals who do not feel their physical security is at risk should have less incentive to return to violence.

Given previous scholarly descriptions of armed groups as goal-seeking, rational actors (Lake and Rothchild 1996; Quinn et al. 2007), an increase in the number of peacekeepers should affect their calculation of the risk of subverting the arrangements imposed by a peace agreement because a larger force places more scrutiny on their movements--raising the likelihood of detection if engaged in 'cheating.' Large groups can expect that any attempts to seize power will be seen by monitors, and if small groups know the former are restrained in such a manner, they should be deterred from preemptively striking. This logic underlies the theory's first hypothesis:

Hypothesis 1: An increase in the number of peacekeepers relative to the state population will decrease the likelihood of peace failure following civil war.

\section{Influence of Political Reforms}

Establishing security should be an immediate concern of peace builders, but creating representative institutions is also a critical step towards long-term state solvency. Unfortunately, holding elections in the wake of a civil war has the potential to reignite conflict, a phenomenon addressed by many scholars of peace building (Snyder 2000; Ottaway 2003; Roberts 2008). Instead of leading to democratic consolidation (and thus in theory, peace), holding elections prematurely seems to undermine stability by encouraging competition when groups to not have the ability to trust one another. In an environment fully secured by a robust peacekeeping force, groups can commit to channeling competition through the non-violent mechanisms of dispute resolution provided by democratic institutions. Therefore, the extent of the third party's commitment to policing former combatants is likely related to instances where elections were 
held successfully (i.e., without causing civil war to recur). The key function of monitoring provided by peace builders supports this conclusion — an independent force can monitor the transition and watch for groups engaged in voter intimidation or manipulation of the electoral process.

Peace building literature has suggested delaying a political transition in post-conflict societies until the electoral process can occur peacefully, but this is unrealistic because most interventions have a limited window of opportunity for reconstruction. Fortunately, recent research found that early elections can be held without violence if peace builders focus on underlying conditions that increase the likelihood that elections will result in democracy instead of violence (Dunning 2011; Flores and Nooruddin 2009; Brancati and Snyder 2012). Brancati and Snyder found that violence after early elections can be reduced under two conditions: a decisive military victory by one party to the conflict, or the presence of an international peacekeeping force that "effectively patrols the country" (23). The 'effectiveness' of patrols in the context of elections should be related to the size of the peace building mission relative to the number of individuals under surveillance, so if elections are held peacefully it will be related to the size of the third party. This relationship should have a negative impact on the probability of peace failure, captured in this paper's second theoretical proposition below.

Hypothesis 2: Elections are less likely to cause conflict in states with a greater number of peacekeepers.

\section{Influence of Economic Development}

If peace builders are interested in preventing the recurrence of war, stimulating economic recovery should be a foremost concern. Results from studies on the interaction between conflict and economic factors indicate that not only are economic concerns - like income inequality- 
more likely to cause civil war than are other sources of grievance (Fearon and Laitin 2003), the use of 'structural adjustment' policies by peace builders may reignite grievances related to economic inequality because they cut government spending and emphasize austerity (Hartzell et al 2010). This decrease in expenditure disproportionally affects impoverished and marginalized populations who rely on the state for assistance, and who in turn become targets of rebel recruitment (Paris 1997). An example of this phenomenon is El Salvador, where elections were held successfully but did not prevent the recurrence of violence. Although political transition was underway, the structural adjustment policies caused per capita income to backslide, which aggravated the economic grievances that led to the previous civil war and fighting subsequently resumed (Paris 2004).

This observation undermines the argument that democratic institutions lead to economic prosperity, and suggests that peace builders could increase cooperation in the political arena by changing their policy towards economic reform in post-conflict states.

Hypothesis 3: A decrease in unemployment preceding an election will decrease the likelihood of renewed fighting following a national election.

To address the 'greedy' motivations for conflict, peace builders can guard against rebellion by creating legal employment alternatives which provide a greater benefit to former combatants than would the resumption of conflict. Since the long-term career prospects for professional rebels are limited to non-existent, former combatants should be favorably disposed to alternative employment. Providing aid and humanitarian assistance can ameliorate grievances in the short-term, but providing jobs for former combatants could be an effective means of increasing the opportunity cost of renewed conflict relative to the utility of remaining employed and unarmed in the long-term (Quinn et al. 2007). 
Observations of how economic factors contribute to civil war support the proposition that peace is facilitated by prosperity. In Sierra Leone, real per capita income dropped from $\$ 1,400$ to $\$ 900$ before the start of their civil war (Sambanis 2004). External pressure to liberalize has been suggested as a contributing factor to the conflict, since privatization led to declining incomes, unemployment, and depressed wages. A reduction in public services followed, spurring resentment and making it easier to recruit individuals to join rebel movements (Taydas et al 2011). The nationalist sentiment that fueled conflict in the Balkans was built on economic selfinterest (Hardin 1995). In some regions of the former Yugoslavia, adult unemployment approached 40 percent in the period immediately before the civil war, and per capita income throughout the country had decreased as a result of liberal reforms in the 1980's (Sambanis 2004). The crisis in the republic began as a disagreement between Serbia and Slovenia over economic sovereignty, and economic issues precipitated crises in other parts of Balkans as well. Unrest in Croatia began with demonstrations against grievances such as high levels of unemployment, and in Kosovo the catalyst for rebellion was a student strike in protest of the deteriorating economic situation (Aleman and Treisman 2005).

If intuitions regarding economic opportunity and individual incentives toward rebellion are correct, lowering the unemployment rate should be negatively associated with post-conflict peace failure, especially if jobs can be provided to young men between the ages of 18 and 35 (as we know them to be the individuals most desired for recruitment by armed groups).

Hypothesis 4: A decrease in unemployment following a civil war will decrease the likelihood of peace failure.

Creating employment opportunities is the ideal policy tool of peace builders, but these reforms are long-term and require time to implement. In the short-term, providing basic social 
services such as food, shelter, and basic health care can reduce grievances by providing the resources individuals need to achieve economic progress on their own. The distribution of human services would also be a signal of accountability to a population which was likely unable to rely on the state previously. If resources are dispersed effectively and predictably, the state could position itself as an alternative to the non-traditional social support structures that form during war to meet basic needs of the population. Simply put, offering public goods is a way to encourage individuals to buy-in to the peace process and commit to peaceful reconstruction; raising the cost of defection and thus reducing the risk of peace failure.

Hypothesis 5: An increase in the amount of public goods supplied will decrease the likelihood of peace failure occurring.

\section{Research Design}

The sample for this paper is peace spells following wars, from 1970 through 2005 . The unit of analysis is country peace spell year based on the data set on peace duration created by Mason et al. (2011), who code a civil war as a conflict with five hundred battle deaths or more. Peace failure, the dependent variable of interest, is coded as the end of a peace spell following a civil war. The end of a peace spell is not exclusive to the resumption of civil war, and includes instances of violence followed by another spell of peace. Describing the variable in this way reflects the phenomena described in our hypothesis-elections may lead to violence without causing another full-scale war, but the occurrence of armed conflict following elections or structural adjustment policies is related to the dependent variable (likelihood of failure) and therefore must be included as indicators for peace failure. Peace failure is a binary variable, and will be coded as 0 if conflict does not recur and 1 if the peace spell is ended by violence. 
The number of peacekeepers is an independent variable that reflects the strength of the third party commitment to peace building. Values for the total number of peace keepers present during the transition process comes from the data set on third party peacekeeping, which tracks peacekeeping missions from 1946-2006 (Mullenbach 2013). These values are then used to create the variable for the ratio of peacekeepers to population, measured as the number of peacekeepers divided by total population. Population is measured using the Correlates of War (COW) National Material Capabilities data. The number of peacekeepers can also be coded as a dummy variable, with 1 coding for the presence of peacekeepers and the absence of peacekeepers coded as 0 .

Data on the first national election comes from Brancati and Snyder 2013. The variable is coded as a binary indicator, with 1 representing a national election in the year of the peace spell. These values will be regressed upon the ratio of peacekeepers described above to create the second model of this paper.

Since data on unemployment and social services in post-conflict countries will not provide enough information to use in the model, hypotheses 3,4 , and 5 must be tested in another way. To estimate the level of economic development, the amount of iron and steel production will be added to the amount of energy consumption (COW National Materials database). This value is divided by the total population to generate the economic variable for the model. Since the quantity of raw materials processed within a country is related to its level of economic development, it can provide a proxy measure of the strength of the national economy. In particular, synchronizing the COW data approximates the strength of domestic industry, as a higher level of energy consumption indicates that more factories and store fronts are operating.

Data is modeled using logistic regression, with peace failure as the dependent variable. The outcome of peace spells will be coded as a binary variable, with 1 representing recurrence of 
conflict following a peace spell, and peace maintenance coded as a 0 . To control for the duration and outcome of previous civil wars (because these are likely to affect the duration of peace), data from Mason et al. will provide measures for these explanatory factors. This data set is also used to control for ethnic fractionalization, presence of a negotiated settlement, the infant mortality rate (IMR) and the number of casualties from the previous civil war.

\section{Results}

The coefficients and standard errors are listed for each model in Table 1. The first models the effect of peacekeeping variables - number of peacekeepers, the ratio of peacekeepers to population, and the peacekeeper ratio squared - on the incidence of peace failure. The second model illustrates the effect of elections on peace failure, and the third reports the relationship between the economic variable and peace failure. All of the relationships are in the predicted direction - peacekeepers have a negative impact on peace failure, as do elections and the economic variable. This is in line with previous research, such as work by Doyle and Sambanis (2006) on peacekeeping; who find that the presence of UN peacekeepers reduces the risk of conflict recurrence. The negative relationship between economic growth and peace failure is as posited by Collier and Hoeffler (2004), but it is not significant. The instance of a national election reduces the likelihood of peace failure as well, contrary to findings of Brancati and Snyder (2013) as well as Flores and Noorruddin (2012), but there is not a large impact to holding elections despite findings at a confidence level of 95 percent.

Control variables with significance include the squared polity score, ethnic fractionalization, the duration of the previous war, the log of the number of deaths from the conflict, and the log of the population. The squared polity score, which indicates the type of political system present in the country, is significant at the level of 95 percent confidence and 
negatively related to peace failure. Ethnic fractionalization is positively related to the end of a peace spell with 99 percent confidence, which is consistent with previous research on civil war and ethnic divisions. A longer and more deadly war, as measured by duration and number of deaths, is reported as a highly significant negative coefficient when regressed against peace failure, indicating that a more destructive conflict may increase war-weariness and cause the population to desire peace.

As the first column in Table 1 shows, the ratio of peacekeepers to population increases the risk of peace failure, but the coefficient produced by the regression is likely showing the effect of peacekeepers at lower levels of deployment. When the ratio is squared, it changes the coefficient value and decreases the risk. This indicates a curvilinear relationship, which is confirmed by running marginal effects where the independent variable of force size is set at different intervals of strength.

The marginal effects reveal that while all the models have significance, the ratio of peacekeepers to population shown in model one has the most explanatory value. When all other variables are held at their means and the total number of peacekeepers is held at the maximum deployment of 60,000 , increasing the ratio of peacekeepers to population from .5 percent of the population to 1 percent of the population decreases the risk of peace failure from 727 percent to 115 percent. When the ratio is further narrowed, to where peacekeepers represent 1.5 percent of the population, the risk drops dramatically to a 2.4 percent chance of peace failure.

\section{Discussion}

These findings show a curvilinear relationship between the ratios of peacekeepers to population, suggesting that peacekeeping missions occur in areas where conflict is intense and intervention forces are too small to secure the territory. Instead, their presence may exacerbate 
the situation because, while they do not have the capacity to prevent the escalation of low-level violence, they nevertheless represent a foreign occupation to the local population and create tension between indigenous and third party forces. My results explain why large peacekeeping operations are initially associated with a risk of peace failure before analyzing the marginal effect that peacekeepers have on the dependent variable, and demonstrate that when peace builders reach a critical threshold they can mitigate almost all chance of conflict recurrence.

The relationship between force size and peace failure changes when peacekeepers reach a threshold where they represent 1.5 percent of the population under observation. Results of the logit point to this percentage as a footprint that is strong enough to dissuade violence without provoking backlash that would cause the risk of peace failure to rise again. With these results I tentatively confirm the first theoretical hypothesis offered by this work.

The second hypothesis, which posits a negative relationship between elections and violence in the presence of a large peacekeeping force, is statistically significant but does not have a meaningful effect on the likelihood of peace failure. The negative correlation, however, between elections and peace failure has not been observed in previous research, which indicates that controlling for the size of force changes the relationship between elections and post-conflict violence. This is noteworthy because it means security may be a pre-requisite for reforms in other areas, since elections are not associated with peace failure when peacekeepers are held at their maximum level of deployment.

For policymakers, these results indicate that arbitrary levels of deployment to postconflict zones may be counterproductive to peace building missions. The association between a robust force and peace suggest that initial deployments should be significantly larger than the 
size used in the status quo, and that peace builders should consider the population of a country when formulating interventions.

My findings do not support any of the hypotheses beyond the first theoretical proposition regarding size of force and peace failure, but this is unsurprising given the lack of data on unemployment and public goods in the post-war setting. In addition, the proxy variable created from the COW national materials data may not be able to approximate the effect of employment or social services. Future research may find a better proxy variable to represent these economic indicators.

Theories on the importance of security in post-conflict peace building are supported by this research. It seems that security is necessary condition for successful reconstruction, most likely because peacekeepers function as a leviathan in the absence of a functioning state government. When there are enough peacekeepers, they reduce the uncertainty experienced by former combatants and create opportunities for those groups to partake in the peace process.

\section{Conclusion}

If there is a more effective way to stabilize post-conflict states, it may require an increase in the number of peacekeepers and military personnel present during peace building missions. Although previous research did not find a relationship between the size of force used to build peace and the subsequent likelihood of conflict recurrence, the results of the logistic regression show that when peacekeepers as percentage of the population increases, the rate of peace failure declines. For policymakers, the results raise additional questions regarding the predominant approach to post-conflict reconstruction and suggest an alternative strategy for third party intervention. 
This conceptualization of strength of force is the first of its kind within the study of peace building, and could be used by researchers to capture the effect of third party intervention on the activities of local actors during peace building missions. Future research can expand on this project by analyzing why the increase in peacekeepers lowers the risk of peace failure. At the moment I only propose that such a link exists, and the explanation for how the strength of force used by peace builders changes the probability of conflict remains theoretical. 


\section{References}

Alemán, Eduardo and Daniel Treisman. 2005. "Fiscal Politics in 'Ethnically Mined,'

Developing, Federal States: Central Strategies and Secessionist Violence" in Sustainable Peace: Power and Democracy after Civil Wars, eds. Philip G. Roeder and Donald Rothchild. Ithaca: Cornell University Press.

Bellamy, Alex J., and Paul D. Williams. 2010. Understanding Peacekeeping. Cambridge: Polity Press.

Berman, Eli, Jacob N. Shapiro, and Joseph H. Felter. 2011. "Can Hearts and Minds Be Bought? The Economics of Counterinsurgency in Iraq." Journal of Political Economy 119(4): 766-819.

Besley, Timothy and Tortsen Persson. 2011. "The Logic of Political Violence.” The Quarterly Journal of Economics 126(3): 1411-1445.

Brancati, Dawn, and Jack Snyder. 2012. "Time to Kill: The Impact of Election Timing on Postconflict Stability." Journal of Conflict Resolution 00(0):1-32.

Call, Charles and Elizabeth Cousens. 2008. "Ending Wars and Building Peace: International Responses to War-Torn Societies." International Studies Perspectives 9:1-21.

Caplan, Richard. 2005. International governance of war-torn territories. Oxford: Oxford University Press.

Cederman, Lars-Erik. Hug, Simon, and Krebs Lutz. 2010. "Democratization and civil war: Empirical Evidence." Journal of Peace Research, 47(4), 377-394.

Chandler, David. 2006. Empire in Denial: The Politics of State-Building. London: Pluto Press.

Chassang, Sylvain, and Gerard Padro Miquel. 2009. "Economic Shocks and Civil War." Presented at Northwestern University. 1-27.

Cho, Hye Jee. 2004. "Do IMF Programs Discipline Budget Deficits? The Effects of IMF Programs on Government Budget Balance, Expenditure, and Revenue.” Paper presented at the $62^{\text {nd }}$ Annual Meeting of the Midwest Political Science Association, Chicago.

Chopra, Janet. 2002. "Building State Failure in East Timor." Survival, 42(3):27-40.

Clapham, C. 2003. "The Global-Local Politics of State Decay," in When States Fail: Causes and Consequences ed. R.I. Rotberg. Princeton, NJ: Princeton University Press.

Collier, Paul and Anke Hoeffler. 2004. "Greed and Grievance in Civil War." Oxford Economic Papers 56(4): 563-595.

Coyne, Christopher J., and Peter J. Boettke. 2009. "The Problem of Credible Commitment in Reconstruction.” Journal of Institutional Economics 5 (1):1-23. 
Dal Bo, Ernesto and Pedro Dal Bo. 2011. "Workers, Warriors and Criminals: Social Conflict in General Equilibrium.” Journal of the European Economics Association 9(4): 646-677.

Diamond, Larry. 2006. "Promoting Democracy in Post-Conflict and Failed States: Lessons and Challenges." Taiwan Journal of Democracy 2 (2): 93-116.

Dobbins, James, Seth G. Jones and Keith Crane, et al. 2005. The U.N's Role in Nation Building: From the Congo to Iraq. Santa Monica: RAND Corporation.

Doyle, Michael W., and Nicholas Sambanis. 2000. "International Peace Building: A Theoretical and Quantitative Analysis.” American Political Science Review, 94(4):779-801.

- 2006. Making War and Building Peace: United Nations Peace Operations. Princeton: Princeton University Press.

Dunning, Thad. 2011. "Fighting and Voting: Violent Conflict and Electoral Politics." Journal of Conflict Resolution 55(3):327-329.

Edelstein, David M. 2009. "Foreign Militaries, sustainable institutions, and postwar statebuilding" in The Dilemmas of Statebuilding: Confronting the contradictions of postwar peace operations. Eds. Roland Paris and Timothy D. Sisk. New York: Routledge.

Englebert Pierre and Denis M. Tull. 2008. "Postconflict Resolution in Africa: Flawed Ideas about Failed States.” International Security 32(4):111- 135.

Fearon, James D. and David Laitin. 2003. "Ethnicity, Insurgency, and Civil War." American Political Science Review 97(1):1-16.

Flores, Thomas Edward, and Irfan Nooruddin. 2009. "Democracy under the Gun: Understanding Post-Conflict Economic Recovery.' Journal of Conflict Resolution 53 (1):3-29.

- 2012. "The Effect of Elections on Post conflict Peace and Reconstruction." The Journal of Politics 74(2):558-570.

Fortna, Virginia Page. 2003. "Inside and Out: Peacekeeping and the Duration of Peace after Civil and Interstate Wars.” International Studies Review 5(4): 97-114.

Hartzell, Caroline A., Hoddie, Mattew and Molly Bauer. 2010. "Economic Liberalization via IMF Structural Adjustment: Sowing the Seeds of Civil War?" International Organization 64(2) 339-356.

Heldt, Birger. 2002. "Conditions for Successful Intrastate Peacekeeping Missions.” Presented at The Cornwallis Group VI: Analysis for Assessment, Evaluation, and Crisis Management.

Höglund, Kristine, Jarstad, Anna K. and Mimmi Söderberg Kovacs. 2009. "The Predicament of Elections in War-torn Societies." Democratization 16(3): 530-557. 
Jarstad, A.K and Timothy D. Sisk. 2008. From War to Democracy. Cambridge: Cambridge University Press.

Keefer, Philip. 2010. "Why follow the leader? Collective action, credible commitment and conflict." in Oxford Handbook of the Economics of Peace and Conflict eds. Michelle Garfinkel and Stergios Skaperdas. Washington, D.C.: The World Bank.

Krause, Keith and Oliver Jutersonke. 2005. "Peace, Security and Development in Post-Conflict Environments.” Security Dialogue 36(4): 447-462

Labonte, Melissa. 2004. "Humanitarian Actors and the Politics of Preventive Action." in Building Sustainable Peace, eds. Tom Keating and W. Andy Knight

Lake, David and Matthew Baum. 2001. "The Invisible Hand of Democracy: Political Control and the Provision of Public Services." Comparative Political Studies 34(6):662-650.

Lake, David, and Donald Rothchild. 1996. "Containing Fear: The Origins and Management of Ethnic Conflict.” International Security 21(2):41-75.

Lemay-Herbert, Nicolas. 2009. "Statebuilding without Nation-building? Legitimacy, State Failure and the Limits of the Institutionalist Approach." Journal of Intervention and Statebuilding 3(1): 21-45.

MacGuinty, Roger. 2008. "Indigenous Peace-Making versus the Liberal Peace.” Cooperation and Conflict 43(2).

Mahdavi, Saeid. 2004. "Shifts in the Composition of Government Spending in Response to External Debt Burden.” World Development 32(7): 1139-1157.

Mansfield, Edward D. and Jack Snyder. 2005. Electing to Fight: Why Emerging Democracies Go to War. Cambridge, MA: MIT Press.

Mason, T. David, Gurses, Mehmet and Patrick T. Brandt, et al. 2011. "When Civil Wars Recur: Conditions for Durable Peace after Civil Wars." International Studies Perspectives 12(2):171-189.

Marten, K. Z. (2004) Enforcing the Peace: Learning from the Imperial Past. New York: Columbia University Press.

McBride, Michael, Gary Milante, and Stergios Skaperdas. 2011. "Peace and War with Endogenous State Capacity." Journal of Conflict Resolution 55(3): 446-468.

Mullenbach, Mark J. 2006. "Reconstructing strife torn societies: third party peace building in intrastate disputes." in Conflict Prevention and Peace building in Post-War Societies eds. T. David Mason and James D. Meernik. New York: Routledge.

Nooruddin, Ifran, and Joel W. Simmons. 2006. "The Politics of Hard Choices: IMF Programs and Government Spending." International Organization 60(4):1001-1033. 
Ottaway, Marina. 2003. "Promoting Democracy after Conflict: The Difficult Choices." International Studies Perspectives 4:314-22.

Pushkina, Darya. 2006. "A Recipe for Success? Ingredients of a Successful Peacekeeping Mission.” International Peacekeeping 13(2):133-149.

Paris, Roland and Timothy D. Sisk. 2009. "Conclusion: confronting the contradictions" in The Dilemmas of Statebuilding: Confronting the contradictions of postwar peace operations eds. Roland Paris and Timothy D. Sisk. New York: Routledge.

Paris, Roland (1997) "Peace building and the Limits of Liberal Internationalism." International Security, 22(2): 54-89.

(2004) At War's End: Building Peace after Civil Conflict. Cambridge:

Cambridge University Press. $36(2): 337-365$.

Quinn, J. Michael, T. David Mason, and Mehmet Gurses. 2007. "Sustaining the Peace: Determinants of Civil War Recurrence.” International Interactions 33: 167-193.

Reilly, Benjamin (2004) "Post Conflict Elections: Constraints and Dangers" in Recovering from Civil Conflict: Reconciliation, Peace and Development. Eds. Edward Newman and Albrecht Schnabel. London: Frank Cass Publishers.

Roberts, David. 2008. "Post-conflict Statebuilding and State Legitimacy: From Negative to Positive Peace?" Development and Change 39(4): 537-555.

Rotberg, R., 2004. "The Failure and Collapse of Nation-states. In R. Rotberg, ed. When States Fail: Causes and Consequences. Princeton: Princeton University Press, 1-49.

Sambanis, Nicholas. 2004. "Using Case Studies to Expand Economic Models of Civil War." Perspectives on Politics 2(2): 259-279.

Schwarz, Rolf, 2005. "Post-Conflict Peace building: The Challenges of Security, Welfare and Representation." Security Dialogue 36(4): 429-446.

Sisk, Timothy D. (2009) "Pathways of the Political: Electoral Processes after Civil War" in The Dilemmas of Statebuilding: Confronting the Contradictions of Postwar Peace Operations eds. Roland Paris and Timothy D. Sisk. New York: Routledge.

Suhrke, Astri. 2009. "The Dangers of a Tight Embrace: Externally Assisted Statebuilding in Afghanistan." in The Dilemmas of Statebuilding: Confronting the contradictions of postwar peace operations. eds. Roland Paris and Timothy D. Sisk. New York: Routledge.

Taydas, Zeynep, Jason Enia, and Patrick James. 2011. "Why Do Civil Wars Occur? Another Look at the Theoretical Dichotomy of Opportunity versus Grievance." Review of International Studies 37(5): 2627-2650. 
Walter, Barbara F. 1999. "Designing Transitions from Civil War: Demobilization, Democratization, and Commitments to Peace." International Security 24 (1):127-55.

Weinstein, Jeremy. 2005. “Autonomous Recovery and International Intervention in Comparative Perspective." Working Paper no. 57. Washington, D.C.: Center for Global Development.

Zartman, William. 1995. Elusive Peace: Negotiating an End to Civil Wars Washington, D.C.: Brookings Institute.

Zaum, Dominik. 2012. "Beyond the 'Liberal Peace'.” Global Governance 18(1): 121-132. 
Table 1: Logit Analysis of Peace Failure

\begin{tabular}{|c|c|c|c|}
\hline Variable & Model 1 & Model 2 & Model 3 \\
\hline Number of & -.0003 & -.0003 & -.0003 \\
\hline Peacekeepers & $(.0001)^{* *}$ & $(.0001)^{* *}$ & $(.0001)^{* *}$ \\
\hline \multirow{2}{*}{$\begin{array}{c}\text { Ratio of Peacekeepers } \\
\text { to Population }\end{array}$} & 2788.88 & 2843.728 & 2807.52 \\
\hline & $(959.5)^{* * *}$ & $(999.41)^{* * *}$ & $(991.74)^{* * *}$ \\
\hline \multirow{2}{*}{$\begin{array}{c}\text { Ratio of Peacekeepers } \\
\text { to Population2 }\end{array}$} & -320822.6 & -331326.8 & -328566.8 \\
\hline & $(112156.2)^{* * *}$ & $(118680.8)^{* * *}$ & $(118018.8)^{* * *}$ \\
\hline \multirow{2}{*}{ Negotiated Settlement } & .24 & .26 & .26 \\
\hline & $(.43)$ & $(.43)^{* * *}$ & $(.41)$ \\
\hline \multirow{2}{*}{ Polity Score Squared } & -.02 & -.02 & -.02 \\
\hline & $(.007)^{* *}$ & $(.007)^{* *}$ & $(.007) * *$ \\
\hline \multirow{2}{*}{$\begin{array}{l}\text { Ethnic } \\
\text { Fractionalization }\end{array}$} & 1.57 & 1.41 & 1.41 \\
\hline & $(.55) * * *$ & $(.52) * * *$ & $(.53) * * *$ \\
\hline \multirow{2}{*}{ War Duration } & -.07 & -.07 & -.07 \\
\hline & $(.03)^{* * *}$ & $(.03)^{* * *}$ & $(.03)^{* * *}$ \\
\hline \multirow{2}{*}{$\begin{array}{l}\text { Log of Number of } \\
\text { Military Personnel }\end{array}$} & .004 & -.45 & -.48 \\
\hline & $(.006)$ & $(.24)^{*}$ & $(.26)$ \\
\hline \multirow{2}{*}{$\begin{array}{l}\text { Log of Number of } \\
\text { Deaths }\end{array}$} & -.004 & .29 & -.48 \\
\hline & $(.002)^{* *}$ & $(.097)^{* * *}$ & $(.099) * * *$ \\
\hline \multirow{2}{*}{ Infant Mortality Rate } & .22 & .004 & .005 \\
\hline & $(.24)$ & $(.005)$ & $(.005)$ \\
\hline \multirow{2}{*}{ Log of Population } & $(.07)$ & .26 & .27 \\
\hline & $(.03) * * *$ & $(.25)$ & $(.26)$ \\
\hline Any Election Occurs & -- & -.79 & -.76 \\
\hline
\end{tabular}




\begin{tabular}{|cccc|}
\hline & & $(.3)^{* * *}$ & $(.31)^{* *}$ \\
Economic Variable & -- & -- & .07 \\
$\mathrm{~N}$ & 1077 & 1077 & 1077 \\
Wald Chi Square & 134.34 & 174.46 & 184.93 \\
\hline
\end{tabular}

Robust standard errors reported in parentheses. Asterisks indicate significance, * 90\% confidence, **95\% confidence, and *** 99\% confidence. 